\title{
SOCIALIZATION OF STATE PROSECUTORS IN SOLVING CIVIL CASES OUTSIDE THE COURT IN THE WORKING AREA OF THE STATE PROSECUTORS OF CENTRAL ACEH
}

\author{
Adenan Sitepu \\ Kejaksaan Negeri Aceh Tengah, Aceh, Indonesia \\ Email: adenanstp75@gmail.com
}

\begin{abstract}
The socialization activity for the duties of the state attorney general in the Takengon area. It is base on observations and interviews conducted with the public and government institutions, which show a common understanding of the prosecutor's duties in representing the state regarding the settlement of cases outside the court in the civil sector. Considering the large number of civil cases currently going to court and requiring a long time to wait for a decision, the non-litigation method of resolving cases is a very efficient and effective alternative when viewed from the benefits obtained. The purpose of restoring state finances can realize. The solution offered by the Datun team in overcoming these problems is to carry out socialization activities on the duties and functions of state attorneys in the non-litigation settlement mechanism to the public and government institutions.
\end{abstract}

Keywords: Socialization, Prosecutors, Civil Cases, Non Litigation

\begin{abstract}
Abstrak: Kegiatan sosialisasi tugas jaksa pengacara negara ini dilaksanakan di daerah Takengon. Hal ini didasari hasil observasi dan wawancara yang dilakukan kepada masyarakat dan lembaga pemerintah, dimana menunjukkan rendahnya pemahaman tentang tugas kejaksaan dalam mewakili negara tentang penyelesaian perkara di luar pengadilan di bidang perdata. Mengingat banyaknya kasus-kasus perdata yang saat ini masuk ke pengadilan dan membutuhkan waktu yang lama dalam menunggu putusan, maka metode penyelesaian perkara secara non litigasi menjadi alternatif yang sangat efisien dan efektif bila ditinjau dari manfaat yang diperoleh. Sehingga tujuan pemulihan terhadap keuangan negara dapat terlaksana. Solusi yang ditawarkan tim Datun dalam mengatasi permasalahan tersebut adalah dengan melaksanakan kegiatan sosialisasi tugas dan fungsi jaksa pengacara negara dalam mekanisme penyelesaian non litigasi kepada masyarakat dan lembaga pemerintah.
\end{abstract}

Kata Kunci: Sosialisasi, Jaksa, Perkara Keperdataan, Non Litigasi

\section{Introduction}

Law enforcement in Indonesia is essentially built to encourage real awareness and change in mental attitudes and foster a mindset where the legal position is not seen and positioned as a mere set of norms but is also a means and tool in changing society. The law is closely connected and inseparable from human life as the object of its regulation, human life, and this law intersects in creating an order. Therefore, Roeslan Saleh said that the law should be studied, and so it is consistently applied continuously in everyday life and activities, even though there are revisions according to the actual situation (Saleh, 1991). Furthermore, L. M. Friedman in Marwan Efendi said that it is necessary to build legal sub-systems in legal development, such as legal substance, legal structure, and legal culture (Effendi, 2005).

Law Number 25 of 2000 concerning the National Development Program (Propernas) 2000-2004 generally provides a step forward from the juridical aspect to develop Indonesia from various sides. One regulation aspect is developing law, which is 
contained in Chapter III (Law No. 25, 2000). The settlement of cases out of court (nonlitigation) is also regulated in the law. The purpose of the regulation above can be understood that the position of justice enforcers today still has many weaknesses that cannot protect the wider community. Thus, the public's trust in the judiciary, especially the prosecutor's office, has not appeared as expected. Building a perfect legal system requires development from the aspect of the legal structure. This aspect is one of the legal systems, one of which is the legal structure of the prosecutor's office as a prosecutor in criminal cases and also representing the state in civil matters.

That civil authority is no less important to know because this authority is concerned with representing the state and government outside and inside the court. So far, the general opinion is that the position and authority of the prosecutor's office are more popular with the authority in the criminal field than the authority in the civil field. In fact, if viewed from the history of the prosecutor's authority in the civil field, it has existed since the past.

As people's lives develop, the community's need for a law will increase, likewise, with implementing the prosecutor's duties in the civil field. At first, it was not well known in the community, but now the implementation of these tasks is becoming known along with the increasing need for authority to solve problems. Out of court on behalf of the state and government (Article 30 Paragraph (2) of Law No. 16, 2004).

Based on reports from 2017 to 2020, 50 (fifty) cases were resolved out of court by the Central Aceh District Attorney (Report: Kasi DATUN, Central Aceh District Attorney, 2021). The settlement of cases in court is certainly a common thing in society, but the settlement of cases outside the court is still unknown to the public regarding the legal basis that regulates the implementation of tasks that have been given extraordinary powers to represent the state or government. By presenting this study, it is hoped that in the future, the Central Aceh District Attorney in particular and the Indonesian public prosecutor, in general, can boost the quality of existing state attorneys to master the knowledge and expertise of qualified civil law in order to understand the implementation of the tasks outlined in the legislation. -invitation. Furthermore, in the future, state attorneys will also continue to improve their skills in legal procedures for resolving cases so that government agencies that entrust legal services respond positively and the results obtained are maximized according to the objectives of Article 30 paragraph (2) of Law Number 16 of 2004 concerning the Indonesian Attorney General's Office.

Based on the explanation above, there is a growing desire to carry out more comprehensive socialization regarding implementing the prosecutor's duties in resolving civil cases outside the court at the Central Aceh District Attorney. From the explanation stated previously, the objective of this socialization is to explain the implementation of the prosecutor's duties to represent the state in resolving civil cases outside the court at the Central Aceh District Attorney.

\section{Method}

The main problem in this socialization is developing and providing information 
about state attorneys' existence to the public and government agencies. The organizer of this activity prepares everything needed for the smooth and successful implementation of the activity. The approaches and methods used to achieve this socialization goal can be seen in Table 1.

Table 1. Objectives and Methods of Extension

\begin{tabular}{|c|c|c|c|}
\hline No & oals & Method & Forms of Activity \\
\hline 1 & $\begin{array}{l}\text { It is necessary to convey } \\
\text { knowledge regarding the } \\
\text { duties of the State } \\
\text { Attorney. }\end{array}$ & $\begin{array}{c}\text { Lectures } \\
\text { and } \\
\text { Discussions }\end{array}$ & $\begin{array}{l}\text { Conduct socialization to the public and } \\
\text { government institutions in Takengon } \\
\text { regarding the Civil and State } \\
\text { Administration Section. }\end{array}$ \\
\hline 2 & $\begin{array}{l}\text { To provide an } \\
\text { understanding of the } \\
\text { duties and functions of the } \\
\text { state attorney general to } \\
\text { the public and government } \\
\text { agencies. }\end{array}$ & $\begin{array}{l}\text { Lectures } \\
\text { and } \\
\text { Discussions }\end{array}$ & $\begin{array}{l}\text { Provide counseling to the public and } \\
\text { government institutions about state } \\
\text { attorneys having duties and functions in } \\
\text { their jurisdictions' civil and state } \\
\text { administration fields. }\end{array}$ \\
\hline
\end{tabular}

\section{Results and Discussion}

\section{Dissemination of the Implementation of the Prosecutor's Duty to Represent the} State in the Process of Settlement of Civil Cases Outside the Court at the Central Aceh District Prosecutor's Office

This socialization activity was given to residents and government institutions in

Central Aceh. As for what was conveyed in this socialization such as:

a. Job and function

The Civil and State Administration Section has the duties and functions of the Prosecutor's Office in the civil and state administration fields in its jurisdiction. In carrying out its duties, the civil and state administration section carries out the following functions: 1) Preparation of materials for the preparation of work plans and programs; 2) Implementation of law enforcement, legal assistance, legal considerations, and other legal actions, as well as legal services in the field of civil and state administration; 3) Coordination and synchronization of policy implementation in the field of civil and state administration; 4) Implementation of working relations with agencies or institutions both domestically and abroad, and 5) Monitoring, analysis, evaluation, and reporting on the implementation of law enforcement, legal assistance, legal considerations, and other legal actions, as well as legal services in the civil and state administration fields.

b. The Civil and State Administration Section consists of 1) Civil Subsection; the civil subsection has the task of providing legal assistance in the civil sector and arbitration forums and law enforcement. 2) State Administration Subsection; state administration subsection has the task of carrying out the provision of legal services in the field of state administration. 3) Legal Consideration Subsection; legal 
consideration subsection has the task of carrying out legal considerations, other legal actions, and legal services in the civil sector.
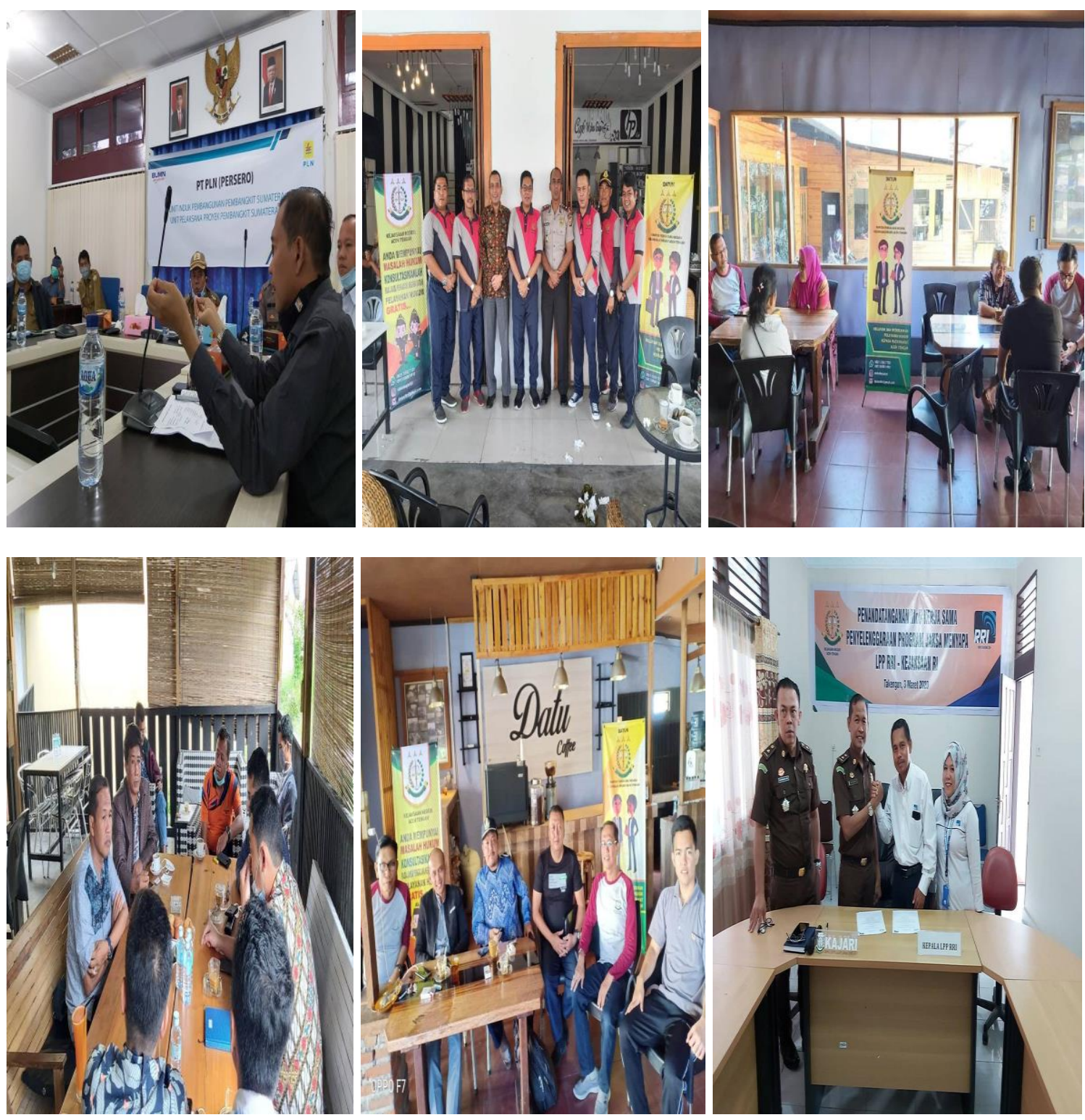

Pictures 1. Socialization Activities in Various Places

\section{Evaluation and Obstacles in Socializing the Settlement of Civil Cases}

A. Internal Constraints

a. Rules of law regarding the settlement of civil cases

In-Law No. 16 of 2004, the Attorney General's Office of the Republic of Indonesia has regulated the prosecutor's authority in Article 30 paragraph (1) to paragraph (3). In handling civil cases, what is lacking is the legal rules that prosecutors must follow, especially in the settlement of non-litigation cases. If litigation cases concerning formal law, of course, refer to the civil code and other regulations of a civil nature, and the source of the material law is base on the Civil Procedure Code. However, if the case is resolved by non-litigation, there is no 
uniform technical rule. As a professional institution, this rule and other methods should be used as long as it does not violate legal and moral provisions.

b. There are no rules regarding state institutions that are worthy of being represented by the prosecutor's office

In-Law no. 16 of 2004, a prosecutor is given dual authority in carrying out law enforcement duties concerning the Indonesian Attorney General's Office. On the one hand, the prosecutor is given the authority to carry out prosecutions in criminal cases, while on the other hand, a prosecutor must also be able to resolve civil cases inside and outside the court.

However, this will be difficult if there are no further regulations from Law no. 16 of 2004, which is clear regarding the limitations that the prosecutor must carry out in resolving these cases so that the position of a prosecutor will be difficult in carrying out his duties. From time to time, there must be legal clashes between illegal settlements and civil cases. For example, a prosecutor handles and settles a civil case, and the defendant is a government agency, then the prosecutor represents the state as a state attorney. On the one hand, the prosecutor acts as a lawyer to protect his client, but if his client deviates from the rule of law, a prosecutor is also obliged to protect his client. It is not a prosecutor also a supervisory agency and a prosecutor if there are violations of law committed by government agencies. So if this is not resolved, there will be ambiguity or something like a legal drama. This will lead to the attitude of a prosecutor knowing that the institution or state agency is not clean from the criminal aspect, but from the civil aspect, a prosecutor must defend the institution. So this confuses law enforcement in Indonesia.

\section{B. External Constraints}

a. Some government agencies are not ready to accept the prosecutor as a partner

The position of the prosecutor's office as a law enforcement agency has always seemed to only deal with criminal matters. This view has become a separate doctrine. Thus, government agencies are reluctant to deal with the prosecutor's office. This reluctance is certainly not unreasonable, and this happens because there are two different factors. First, government agencies, both BUMN and BUMD, have become accustomed to past habits that are always not transparent in carrying out the agency's policies. This past habit continues until now so that for some institutions and agencies, it will be uncomfortable if things that are not transparent are known by other institutions, especially the prosecutor's office. Second, the internal affairs of the government institutions must make rules and understandings that sometimes some agencies are not ready to accept the reforms that are needed for development towards the improvement of these government agencies.

b. The number of institutions that are not clean

This classic constraint has taken root, so it needs special handling to change it. Unclean institutions will certainly avoid partners with the prosecutor's office. Because with the inclusion of the prosecutor as a partner, it is possible that depravity will appear and will become a new problem. This issue may result in two 
opposite things. On the one hand, the prosecutor's office will expose depravity because the government agency is not clean.

On the other hand, there will also be a mutual agreement that will cover up the depravity with taking and give. These possibilities will continue to occur. Therefore, institutions that are not clean tend to be less accepting of the prosecutor as a partner.

\section{Conclusions}

The socialization activities concluded several things:1) The implementation of the tasks of the Central Aceh District Attorney's Office in resolving cases outside the court is essential, especially in civil cases. Considering the large number of civil cases currently entering the court and requiring a long time to wait for a decision, this non-litigation method of case settlement is a very efficient and effective alternative when viewed from the benefits obtained so that the purpose of restoring state finances can be realized. 2) The obstacles faced by the Central Aceh District Prosecutor's Office in completing the implementation of the prosecutor's duties outside the court in the civil sector are that there are no standard rules regarding the non-litigation settlement mechanism. In addition, other obstacles are government agencies that are not ready to be partners with the prosecutor's office because of the lack of transparency in these institutions and many government agencies that are not clean, so they think that cooperation with the prosecutor's office will cause new problems.

\section{Thank-you Note}

The outreach team would like to express their deep gratitude to all those who have helped and been involved in the implementation of this activity. Then to jurnal pengabdian masyarakat (JPMA) As-Salam who has published this activity report.

\section{References}

Effendi, Marwan. (2005). Kejaksaan Republik Indonesia, Posisi dan Fungsinya dari Perspektif Hukum. Jakarta: PT. Gramedia Pustaka Utama.

Saleh, Marwan. (1991). Suatu Peringatan Bagi Cendekiawan Hukum Indonesia. Jakarta: Lembaga Pengkajian Hukum Universitas Muhammadiyah.

Sumber Laporan: Kasi Perdata dan Tata Usaha Negara (DATUN) Kejaksaan Negeri Aceh Tengah, Periode Januari 2017 sampai dengan Desember 2020 (Takengon: Kejaksaan Negeri Aceh Tengah, 2021) 10 Januari 2021.

Himpunan Petunjuk Jaksa Agung Muda Perdata dan Tata Usaha Negara (JAM DATUN), XXII (Jakarta: Kejaksaan Agung RI), 12.1997

Pasal 30 Ayat (2) Undang-Undang No. 16 Tahun 2004 Tentang Kejaksaan Republik Indonesia (Republik Indonesia, 2004).

Peraturan Kolonial Stb. 1922 No. 522 Tentang Vertegenwoordiging Van De Land In Rechten (Kolonial Belanda, 1922).

Peraturan Presiden RI Nomor 38 Tahun 2010 tentang Organisasi dan Tata Kerja Kejaksaan Republik Indonesia (Repuplik Indonesia, 2010). 
Peraturan Jaksa Agung Nomor PER-018/A/J.A/07/2014 Tahun 2014 tentang Standar Operasional Prosedur pada Jaksa Agung Muda Bidang Perdata dan Tata Usaha Negara (Jakarta, 2014).

Undang-Undang No. 25 Tahun 2000 Tentang Program Pembangunan Nasional (PROPENAS) Tahun 2000-2004 (Republik Indonesia, 2000).

Undang-Undang No. 16 Tahun 2004 Tentang Kejaksaan Republik Indonesia (Republik Indonesia, 2004). 